CEB Working Paper

\title{
Do Banking Crises Improve Democracy?
}

\section{Beni Kouevi-Gath, Pierre-Guillaume Méon, Laurent Weill}

We study the impact of banking crises on the level of democracy. We use an event-study method on a sample of up to 129 countries over the period 19752010 accounting for 94 systemic banking crises. We find that banking crises are followed by an improvement in democracy and report evidence suggesting that the relation is causal. The bulk of the improvement takes place between 3 and 10 year after the banking crisis. The impact of a banking crisis is greater in nondemocratic countries and when the banking crisis is severe. We explain this finding by the fact that banking crises create windows of opportunity to contest autocratic regimes.

Keywords: banking crisis, democracy, regime change, transitions.

JEL Classifications: D72, H11.

\section{CEB Working Paper No 19/009 \\ May 2019}

Université Libre de Bruxelles - Solvay Brussels School of Economics and Management Centre Emile Bernheim 


\title{
Do Banking Crises Improve Democracy?
}

\author{
Beni Kouevi-Gath \\ Université libre de Bruxelles (ULB) \\ Centre Emile Bernheim, ECARES \\ CP-139 \\ avenue F.D. Roosevelt, 50 \\ 1050 Bruxelles, Belgium \\ phone: +32-2-650-42-97 \\ e-mail: bkouevig@ulb.ac.be \\ Pierre-Guillaume Méon \\ (corresponding author) \\ Université libre de Bruxelles (ULB) \\ Centre Emile Bernheim \\ CP-114/03 \\ avenue F.D. Roosevelt, 50 \\ 1050 Bruxelles, Belgium \\ phone: +32-2-650-65-99 \\ fax: +32-2-650-41-88 \\ e-mail:pgmeon@ulb.ac.be

\section{Laurent Weill} \\ EM Strasbourg Business School \\ Université de Strasbourg \\ 47 avenue de la Forêt Noire \\ 67082 Strasbourg Cedex \\ phone: $33-3-68-85-81-38$ \\ fax: $33-3-68-85-86-15$ \\ e-mail: laurent.weill@unistra.fr
}

\begin{abstract}
We study the impact of banking crises on the level of democracy. We use an eventstudy method on a sample of up to 129 countries over the period 1975-2010 accounting for 94 systemic banking crises. We find that banking crises are followed by an improvement in democracy and report evidence suggesting that the relation is causal. The bulk of the improvement takes place between 3 and 10 year after the banking crisis. The impact of a banking crisis is greater in non-democratic countries and when the banking crisis is severe. We explain this finding by the fact that banking crises create windows of opportunity to contest autocratic regimes.
\end{abstract}

JEL Codes: D72, H11.

Keywords: banking crisis, democracy, regime change, transitions. 


\section{Introduction}

A recurring theme in Peter Bernholz's work is the sustainability of a "free society" (Bernholz, 1979, 1991, 1995, 2000). His concern that the interaction between the capitalist system and democracy may result in totalitarianism (Bernholz, 2000) therefore prompted him to investigate the causes of changes in political-economic regimes, "defined by the set of relatively stable and long-lasting rules (including the legal system), rights and government organizations within and through which it operates" (Bernholz, 1995, p.74). Although he argued that most historical changes of political-economic regimes were continuous evolutionary processes, he also stressed the role of crises as important turning points (Bernholz, 1991, 1995). In his view, the tendency of democracy to increase the number of regulations and the share of the government in GDP would gradually result in a misallocation of resources, an erosion of the efficiency of the capitalist system, and an eventual crisis.

Such crises may however be either a blessing in disguise or an unmitigated curse (Bernholz, 1995, 2000). On the one hand, they may provide a window of opportunity to implement sound reforms to restore efficiency. The comparison with the performance of other capitalist states and the realization by voters of the inefficiencies caused by regulations could accordingly lead special interest groups to agree, thanks to logrolling, to forego the benefits of the regulations that benefited them at the cost of others. On the other hand, crises are also fertile ground for ideologies offering attractive solutions to the problems perceived by "people who are disoriented and suffering during crises" (Bernholz, 2000 p.14). Those ideologies could turn the nation against democracy and into a totalitarian state. Peter Bernholz (1995, 2000) accordingly viewed the advent of Nazism and communism as consequences of economic crises.

In this paper, we test which of two effects of crises dominates by looking at one specific type of crises: banking crises. A vast empirical literature has shown the deleterious consequences of those crises. They weaken bank lending (e.g. Ivashina and Scharfstein, 2010), reduce employment (e.g. Chodorow-Reich, 2014), and generate output losses (e.g. Hoggarth, Reis, and Saporta, 2002). In a 2010 paper, Peter Bernholz also expressed concern about the institutional consequences of the 2009 financial and banking crisis. He argued that the measures taken to tackle the crisis weakened checks and balances by reducing central bank independence. We study whether banking crises have a broader and more systematic effect on democracy, using an event-study method on a sample of up to 129 countries over the period 1975-2010 accounting for 94 systemic banking crises. 
If the economic consequences of banking crises have been studied in depth, their political and institutional consequences have received less attention, with only a handful of studies investigating this area. Gries and Meierrieks (2013) find that banking crises are associated with greater terrorist activity in developing economies, while Gutmann, Pfaff, and Voigt (2017) show that banking crises deteriorate human rights, in particular in nondemocracies. Andersson (2016) observes that major banking crises enhance the market orientation of economic institutions and the stability and accountability of political institutions.

In line with Peter Bernholz's (2010) contention, we complement the literature by studying whether banking crises affect the level of democracy. Consistent with his view that crises can be either a blessing in disguise or a curse, the effect of banking crises on the level of democracy is a priori ambiguous. First, banking crises could induce democratization. Acemoglu and Robinson (2001) also argue that negative economic shocks reduce the cost of fighting autocratic regimes, generating a window of opportunity to contest power, prompting the autocratic elite to make democratic concessions. In line with this intuition, recent empirical work has observed that economic recessions encourage democratic change (Burke and Leigh, 2010; Brückner and Ciccone, 2011). Thus, banking crises, being major negative shocks to the economy, could serve as a triggering event weakening autocracy.

However, the resolution of banking crises may necessitate painful policies like the closure of banks and losses for depositors, which are difficult to implement in democracies, thereby leading to a democratic breakdown. Moreover, financial crises can foster ideologies antagonistic to democracy (Bernholz, 1995, 2000). In line with this view, Funke, Schularick and Trebesch (2016) observed that financial crises lead to greater votes for far-right parties in a sample of 20 advanced democracies from 1870 to 2014 . This political radicalization takes place after financial crises but not after normal recessions or severe macroeconomic shocks without financial content, which stresses the specific political effects of financial crises. The interpretation is that financial downturns would be considered as less excusable than other crises because they would be perceived as the result of policy failures. As such, financial crises would be detrimental to democracy. Finally, banking crises give autocrats incentives to resort to repression to intimidate citizens. Gutmann, Pfaff and Voigt (2013) explain their finding of a negative impact of banking crises on human rights by the fact that autocrats have two reasons to increase repression during banking crises. On the one hand, increased unemployment generates greater grievance in the population which can lead to a revolution. So, autocrats must intimidate citizens through enhanced repression. On the other hand, 
banking crises reduce the ability of autocrats to buy loyalty by giving perks. Therefore, since autocrats use loyalty and repression to stay in power, lower availability of loyalty leads them to foster repression.

To determine which effect dominates, this paper examines how banking crises influence democratic change. To this end, we consider a sample of 129 countries from 1975 to 2010. We combine data on a democracy index from the Polity IV database with data on banking crises from Laeven and Valencia (2012). We perform an event study by regressing the democracy index on a series of dummy variables coding the date of banking crises. We are then able to examine both the magnitude and the timing of the effects of banking crises on democratic change. We furthermore analyze whether the severity of banking crises affects democratic change, defining the severity of banking crises according to their duration and to the peak of non-performing loans.

Our primary finding is that banking crises tend on average to be followed by an improvement in the democracy index. The bulk of the improvement takes place between 3 and 10 years after the banking crisis. We observe no anticipation effect. These results are robust to a battery of robustness tests, including using alternative explanatory variables and techniques. Furthermore, we find that more severe banking crises have a higher impact on democracy. These findings are consistent with the view that banking crises create windows of opportunity to contest autocratic regimes and consequently favor democratic improvements, in line with the first series of mechanisms discussed by Bernholz $(1995,2000)$ or with Acemoglu and Robinson's (2001) model.

With this work, we contribute to three strands of literature. First, we extend the literature on the consequences of banking crises in the direction of democratization. We can then add to the handful of works considering the political effects of banking crises by helping understanding how these crises shape political regimes. Second, we contribute to the burgeoning literature on the impact of banking on political outcomes. Recent works have focused on how lending of state-owned banks can be used to influence elections (Dinc, 2005, Carvalho, 2014, Englmaier and Stowasser, 2017). We extend this literature in the direction of the effects of banking crises. Third, we augment the literature on the causes of democratization by examining the impact of banking crises. The debate on the causes of democratization is far from settled with some arguing that democratization is unpredictable by nature (Kuran 1989, 1991) while others support the influence of some factors (e.g. Acemoglu and Robinson, 2001). Our results suggest that taking banking crises into account would increase the predictability of banking crises. 
The paper proceeds as follows. Section 2 presents the method. Section 3 reports the baseline results. Section 4 displays additional estimations. Section 5 concludes.

\section{Methodology}

\subsection{Econometric Specification}

To study the impact of banking crises on democracy, we use an event study method. The first step to perform such an analysis is to define the event around which we want to measure the evolution of the dependent variable. In our case, the event is defined as the start of a financial crisis.

We then study the evolution of the level of democracy around the event by comparing the level of democracy before and after the beginning of a crisis. To do so, we estimate the following equation:

Demo $_{i t}=\alpha$ Demo $_{i t-1}+\beta B C_{i t}+\sum_{j=1}^{J} \theta_{j} X_{j i t}+\delta_{i}+\mu_{t}+\varepsilon_{i t}$

Where Demo it is country $i$ 's level of democracy in year $t . B C_{i t}$ is our variable of interest. It is a dummy variable that is equal to one for country $i$ in years $t+d,(d=0, \ldots, 10)$ if country $i$ experienced a systemic banking crisis that started in year $t . B C_{i t}$ is equal to zero otherwise. $X_{j}$ is a set of control variables. $\delta_{\mathrm{i}}$ and $\mu_{t}$ respectively represent country fixed effects and year fixed effects. $\varepsilon_{i t}$ is the error term. The lagged dependent variable is included on the right-hand side of Equation (1) to control for the persistence in democracy.

The choice of an event window ending 10 years after the beginning of a banking crisis trades-off the possibility to analyze the long-term consequences of banking crises and the length of the period of study: the longer the study-window the shorter the estimation period. Specifically, if we measure the impact of banking crises $\mathrm{T}$ years after the start, we lose $\mathrm{T}$ years of observations at the beginning of the sample period. On the other hand, a small value of $\mathrm{T}$ limits our time horizon.

Because we control for both country- and year-fixed effects in addition to the lagged democracy index, coefficient $\beta$ measures the annual change in its democracy indx that a country experiences after the beginning of a banking crisis. In other words, the method measures the effect of a treatment consisting in experiencing a financial crisis. The treated 
group is the group of countries that have endured a crisis while the control group consists of the countries that have not.

\subsection{Data}

Our dependent variable measuring democracy is the polity2 democracy score. This variable comes from the Polity IV database of Marshall, Gurr and Jaggers (2016). ${ }^{1}$ They code political regimes by combining different scores based on the competitiveness of political participation, the openness and competitiveness of executive recruitment, constraints on the chief executive, and the regulation of participation. The scores are then converted to be adapted to time-series analysis to form the polity 2 variable. The resulting polity 2 scores range from -10 to $+10 .^{2}$ The highest scores indicate the most democratic regimes while the lowest scores indicate the most autocratic regimes. They provide a continuous measure of a country's degree of democracy, which is in line with the notion that institutional changes may be gradual (Bernholz, 1991, 1995).

To identify systemic banking crises, we use the dataset constructed by Laeven and Valencia (2008, 2012). This database is commonly used in works on banking crises (e.g., Caballero, 2014). It identifies a banking crisis in a country in a year when two criteria are met: the financial and real sectors experience a financial distress, and significant policy measures are put in place in order to limit the real consequences of the banking crisis.

The financial and real sectors experience a financial distress when the banking system encounters heavy losses (when the share of non-performing loans exceeds $20 \%$ ) and/or bank liquidation takes place, in addition to considerable bank runs (when deposits drop by more than $5 \%$ from one month to another).

To consider that significant policy measures are put in place, at least three out of six following conditions must be fulfilled:

An extensive liquidity support. This condition is satisfied if the liquidity support is implemented directly by the Treasury, or if the ratio of central

\footnotetext{
${ }^{1}$ We test the robustness of our results when using another measure of democracy in the robustness check section. ${ }^{2}$ We use the polity 2 variable with a slight modification. The database assigns a zero score to the index in periods where politics cannot exercise effective authority over at least half of their territory due to foreign intervention. These are the so-called interregnum periods. For our analysis, we treat these observations as missing. The reason is that since we are interested in the evolution of democracy, we want to avoid misinterpretation of improvement or deterioration relative to preceding years. For instance, suppose a country has a negative score of democracy in year $t-1$. Then, if that country experiences a foreign intervention in year $t$, we will interpret it as an improvement in democracy according to the initial database. The reverse holds for a country that has a positive score of democracy in year $t-1$ and a foreign intervention in year $t$. We thus decide to treat observations related to interregnum periods as missing values. This results in the deletion of 70 out of 4680 observations in our sample.
} 
bank claims on the financial sector to deposit and foreign liabilities exceeds $5 \%$, or more than doubles compared to its pre-crisis level;

- $\quad$ Bank restructuring takes place as a result of the banking system's difficulties so that the gross fiscal costs of banks' restructuring exceed 3\% of GDP.

- $\quad$ Assets purchases by the Treasury or the central bank exceeds 5\% of GDP.

- $\quad$ Bank nationalization;

- Guarantees on banks' liabilities (full protection or extended to non-deposit liabilities);

- $\quad$ Deposit freezes and/or bank holidays.

One advantage of Laeven and Valencia database is that it identifies only systemic banking crises. Conversely isolated banking crises that do not spread to the whole system are not considered. This is important for our study since minor crises can be too limited to affect the political regime.

In Laeven and Valencia's (2012) dataset, a systemic banking crisis ends in year $t$ when both real GDP growth and real credit growth are positive for two consecutive years for year $t+1$. In case real GDP growth and real credit growth are positive for the first two years, then the end and start years are identical. When information on credit growth is missing, only real GDP growth is considered in the definition. In all cases Laeven and Valencia (2012) limit the maximum duration of a banking crisis to 5 years, starting from the first year of the crisis.

Out of the 129 countries in our sample, 79 experienced at least one systemic banking crisis over the period 1975-2010, for a total number of 94 systemic banking crises. Table A1 in appendix lists the countries considered in our study as well as the banking crises they experienced during our period of study.

Since we want to analyze the democracy level 10 years after a banking crisis started, we have to delete observations pertaining to the 10 first years of our sample $(T=10)$ for the estimations. Though we restrict our sample period to 1975-2010, we can use Laeven and Valencia's dataset to check the absence of any systemic banking crisis during the period 1970-1975. The first banking crises in that database happened in 1976 (in the Central African Republic and Chile). However, we cannot use Laeven and Valencia's dataset to go back further in time. We thus make use of Reinhart and Rogoff (2009) dataset to investigate the occurrence of banking crises over the period 1965-1970. This widely used dataset of banking crises is less restrictive than the previous one as it considers all banking crises, including nonsystemic ones.

Reinhart and Rogoff's (2009) dataset reveals that there were no banking crises over 
the period $1965-1970 .^{3}$ Therefore, requiring that $\mathrm{T}=10$ is equivalent to deleting 10 years of observations at the beginning of our sample period, while analyzing long-term consequences at the same time.

Some countries experienced several systemic banking crises over the sample period. In our dataset, this accounts for 15 countries. For these countries, defining the pre-crisis and post-crisis periods is confusing, especially after the first systemic banking crisis episode. The problem arises only for countries whose time span between the start dates of two successive crises is less than 10 years. In fact, the post-crisis period exceeds 10 years for these countries. The choice of $\mathrm{T}=10$ allows us to reduce this problem. However, as a robustness check, we will present the results for a sample that excludes countries with more than one systemic banking crisis, so as to make sure that this coding logic for these countries does not affect our results.

A country that needs a particular discussion is Brazil. According to the Laeven and Valencia (2012) dataset, this country experienced two successive banking crises: from 1990 to 1994 and from 1994 to 1998 . In our analysis, we consider this country as having a single banking crisis that lasts from 1990 to 1998.

Though we measure democracy until 2010, we do not consider the impact of the Global Financial Crisis due to data limitations. We cannot observe the democracy index for the following 10 years.

We will estimate Equation (1) by ordinary least squares with robust standard errors clustered at the country level. The validity of our method requires at least two conditions. The first is the parallel trend assumption between the treated and control groups. In fact, there should be no pre-existing difference between both groups before the occurrence of banking crises. Otherwise, the estimated coefficient of the banking crisis dummy would not capture the effect of banking crises. We checked explicitly for the parallel trend assumption. The results suggest that we cannot reject the parallel trend assumption. ${ }^{4}$ Later, we also use a modified specification in Section 4 which confirms the absence of any anticipation effects as well.

The second requirement is that the banking crisis dummy should be exogenous. Broadly speaking, there might be underlying factors that make countries particularly

\footnotetext{
${ }^{3}$ We have to stress that considering a larger $\mathrm{T}$ requires further hypotheses about the realization of systemic banking crises over the period before 1970 .

${ }^{4}$ More specifically, we introduce a time trend in our specification and interact it with the banking crisis dummy. A significant coefficient of this interaction variable would indicate a violation of the parallel trend hypothesis. In our case, the p-value associated with the coefficient is 0.49 , suggesting that the parallel trend assumption holds for our data.
} 
vulnerable to banking crises. For instance, banking crises tend to follow periods of high financial leverage and macroeconomic volatility (Demirgüç-Kunt and Detragiache, 1998). However, the exact timing of the occurrence of financial crises in general and banking crises in particular is unpredictable. As argued by Reinhart and Rogoff $(2009$, p.3), almost all major crises are characterized by the "this time is different" syndrome because of "the belief that financial crises are things that happen to other people in other countries at other times; crises do not happen to us here and now. We are doing things better, we are smarter, we have learned from past mistakes. The old rules of valuation no longer apply. Unfortunately, a highly leveraged economy can unwittingly be sitting with its back at the edge of a financial cliff for many years before chance and circumstances provoke a crisis of confidence that pushes it off."

Alternative estimation techniques including a dynamic dependent variable estimator, an instrumental variable estimator, and treatment effect models, are used as robustness checks.

\section{Results}

\subsection{Baseline Results}

Table 1 reports our baseline results. We perform three estimations. We first estimate Equation (1) for the whole sample. We then exclude countries that experienced several episodes of banking crises, since the post-crisis period may exceed 10 years for this subgroup of countries. Finally we exclude the Global Financial Crisis by considering only years until 2007.

We observe that the lagged dependent variable is positive and significant at the one percent level. The coefficient is lower than one. The democracy index is therefore persistent and converges.

The key finding is the positive coefficient of the banking crisis variable that is statistically significant at the five-percent level. This result is observed in all regressions. It therefore stands when we consider the full sample but also when we exclude countries that were hit by several banking crises and when we exclude the Global Financial Crisis, showing the robustness to the result. Our main finding is therefore that the occurrence of a banking crisis is followed by an improvement in the democracy index in the ten following years.

A banking crisis is thus beneficial for democratic change. In other words, our findings 
support the view from Bernholz (1995, 2000) or Acemoglu and Robinson (2001), according to which negative economic shocks create windows of opportunity to contest autocratic regimes and thus favor democratic improvement.

The size of the coefficient varies from 0.196 to 0.219 across the estimations, with 0.196 for the whole sample. It means that the annual increase in democracy index following a banking crisis is about 0.20 .

\subsection{Robustness Checks}

\subsubsection{Alternative specifications}

First, we exclude former socialist countries from the sample. These countries have experienced both a change in their political system and a wave of democratic improvements. The change in their economic system was followed by a period of turbulence in their banking system. One may thus be concerned that our baseline finding be driven by the experience of former socialist countries and therefore not a general consequence of banking crises. In our baseline specification, time and country fixed effects partially take into account this possibility. Nonetheless, we check the robustness of our results by excluding this sub-sample of countries. The results are reported in Column (1) of Table 2. We observe that the coefficient of the banking crises dummy is still positive and statistically significant at the five percent level. This finding confirms that our baseline result is not driven by the sample of former socialist countries.

Second, we control for the international aspect of democratic improvements to make sure that we capture domestic pressures towards democratic reforms. The reason is that many democratic changes appear in the form of waves where a country's democratic change follows that of a cohort. The Arab Spring is an illustration of this movement. To control for the international aspect of democratic change, we compute a regional index of democracy as follows. We start by identifying geographic regions in our sample based on the World Bank's classification. Then, for each country $i$ located in region $j$, we compute the average democracy score of the other countries in the region. We call this variable "regional democracy" and include it among explanatory variables. Column (2) of Table 2 displays the corresponding results. We find that the regional democracy variable is positive and statistically significant at the one-percent level. This means that a country's democracy moves in the same direction as the democracy of its region, which confirms that democratic changes occur in waves. However, the key finding that the coefficient of the banking crises dummy is positive survives the robustness test. The coefficient of the dummy variable is statistically significant at the 
five-percent level, confirming our baseline results. In other words, the improvement in democracy that we observe in the 10 years following the start of a banking crisis mainly comes from domestic pressures.

Third, we use an alternative measure of banking crises. To do so, we rely on the dataset constructed by Reinhart and Rogoff (2009). They construct a banking crisis dummy that takes the value of one in a country in a year characterized by a bank run that leads to the closure, merging, or takeover by the public sector of one or more financial institutions. When there are no bank runs, the banking crisis dummy takes the value of one if the closure, merging, takeover, or large-scale government assistance of an important financial institution (or group of institutions) mark the start of a string of similar outcomes for other financial institutions.

The results of using the banking crises identified by Reinhart and Rogoff (2009) are reported in Column (3) of Table 2. We find that the banking crisis dummy is still positive and statistically significant at the $5 \%$ level, confirming our baseline results. Compared to the latter, the size of the coefficient of the banking crisis dummy is however lower. This is not surprising since the definition of banking crises in Reinhart and Rogoff (2009) is less restrictive than that of Laeven and Valencia (2008, 2012).

Fourth, we control for other income shocks. Namely one can question our identification strategy in the sense of what we interpret as the effect of a banking crisis is in fact the outcome of other income shocks since financial crises often occur in clusters (Reinhart and Rogoff, 2009; Laeven and Valencia, 2012). To this end, we consider three types of shocks: large income shocks, sovereign debt crises, and currency crises. For each type of shock, we consider a different treatment: the treatment for large income shocks refers to the treatment group for countries that experienced large income shocks, and so it is for sovereign debt crises and currency crises.

By defining a different treatment for each type of income shocks, we can check if any of the three shocks exerts an influence on the relation between the occurrence of a banking crisis and the level of democracy. If banking crises have an effect on democracy that is independent of other income shocks, their statistical significance will still be observed even after controlling for these other shocks. The coding of each shock follows the same logic as the banking crisis dummy. That is, we first identify the date of their occurrence. Then we code a dummy variable that takes the value of one in the 10 years that follow their occurrence. Otherwise, it takes the value of zero. 
To identify large income shocks, we rely on Bluhm et al. (2019): they characterize economic slumps as "interruptions of a positive growth regime by a sharp downward shift coinciding with a sequence of two trend breaks". The identification of sovereign debt crises and currency crises is based on Laeven and Valencia (2012). They define sovereign debt crises as years of a sovereign default to the private sector, while currency crises are defined as a nominal depreciation of the currency of at least $30 \%$ that is also at least a $10 \%$ increase in the rate of depreciation compared to the previous year.

The results are reported in Table 3 with each of the three columns adding the dummy variable for one type of income shocks. We observe that the coefficient of banking crises is still statistically significant and positive in all three specifications. Therefore, banking crises have an independent effect on democracy that is not captured by other shocks. Interestingly we also point out that only sovereign debt crises also have a positive impact on the level of democracy, while the effect of large income shocks and currency crises is not significant.

Thus these estimations show that banking crises have an impact on democracy that is independent of other income shocks.

\subsubsection{Alternative Estimation Techniques}

We now turn to robustness checks focusing on alternative estimation techniques. We successively use a dynamic dependent variable estimator, an instrumental variable estimator, and treatment effect models.

First, we utilize a dynamic dependent variable estimator. The presence of the lagged dependent variable among the explanatory variables combined with country fixed effects may result in a Nickell bias. Although, this bias is expected to be limited in our case because we have a large time horizon, we address that possibility by using the Blundell and Bond estimator (SYS-GMM). We only perform it as a robustness check rather than in the baseline estimations since the SYS-GMM estimator is ill-adapted to dummy variables. Given that we have a large time period, we collapse instruments to avoid the issue of instruments proliferation pointed out by Roodman (2009). We use the two-step estimator with small sample correction.

The results are displayed in the first three columns of Table 4. We test the three same specifications than in the baseline estimations: on the whole sample, by excluding countries with several episodes of banking crises, and by excluding the Global Financial Crisis. 
We observe that the banking crises dummy is significant and positive in the three specifications. We thus confirm our baseline results according to which the democracy index improves in the ten years following the start of a banking crisis.

We also report the test related to first-order serial correlation in level by looking at the second-order correlation in differences. We cannot find any evidence of second serial correlation in the error term. We also report the Sargan/Hansen test of instruments' exogeneity. They all point to the exogeneity of the instrument (with the exception of the Sargan test in the specification excluding the Global Financial Crisis).

Second, we address the potential endogeneity concern by re-estimating our baseline specification using an instrumental variable strategy. Our baseline results lead unbiased estimates if banking crises are exogenous. Moreover, our analysis of the timing in the next section does not provide evidence of anticipation effects, which suggests that endogeneity is not a major concern in our case. However, it is difficult to completely rule out endogeneity because of omitted variables or measurement errors. Moreover, one may argue that banking crises are not really exogenous since they can be predicted.

To tackle this problem, we instrument the banking crises dummy variables with two instruments: exposure to external banking crises and capital flow bonanzas.

The first instrument, the exposure to external banking crises is based on the idea that banking crises are contagious. A crisis that starts in a country is easily propagated to other countries through trade and financial relations with the countries where the crisis originates. Proximity may simply be geographic as well. In that case, a banking crisis is propagated to neighboring countries.

To construct this instrument, we first identify geographic regions defined by the World Bank. ${ }^{5}$ Then, we compute the index related to the exposure to external banking crises for country $i$ in region $r$ as follows:

$B C_{i t}^{\text {exposure }}=\frac{1}{T-1}\left(B C_{j t}^{r}-B C_{i t}\right)$, where $B C_{j t}^{r}$ is the sum of banking crises for the remaining countries in the region and $B C_{i t}^{\text {exposure }}$ is our index measuring the exposure to external banking crises.

The second instrument is capital flow bonanzas. This variable was used as an instrument in Gutmann, Pfaff and Voigt (2017) and it is found to be a significant predictor of systemic banking crises (Reinhart and Reinhart, 2013; Reinhart and Rogoff, 2008; Caballero,

\footnotetext{
${ }^{5}$ We use a mix of geographic and economic linkages in the sense that for European countries, we distinguish the ones that are member of the Eurozone from the others. Likewise, for Sub Saharan African countries, we distinguish between West Africa, East Africa and the others.
} 
2014). Caballero (2014) shows that capital flows bonanzas increase the probability that a country experiences a financial crisis through the vulnerabilities it induces in the macroeconomic environment due either to excessive lending or to surges in portfolio-equity.

We extract data on capital flow bonanzas from Reinhart and Reinhart (2008), who code episodes of sudden increase in international capital inflows for 181 countries from 1980 to 2007. When a country experiences a deterioration of its current account that exceeds the $20^{\text {th }}$ percentile threshold, it is classified as undergoing a capital flow bonanza. Once we identify the date of capital flow bonanzas, our instrumental variable takes the value of one in the ten years that follow the beginning of a capital flow bonanza and zero otherwise.

The exclusion restriction assumption for both instruments is that, conditional on country fixed effects, year fixed effects, and lagged democracy, imported banking crises and capital flow bonanzas do not have a direct impact on the democracy of that country except through their influence on domestic banking crises. This assumption may be too restrictive. In fact, it may happen that banking crises in a region prompt a democratic change in that region which spills over to the domestic country, without affecting the fragility of the financial sector of the latter. The regional crisis would thus affect domestic democracy via regional waves of democracy. Likewise, one may argue that autocratic regimes might use the resources from capital flow bonanzas to direct lending towards particular firms or to consolidate their regime with no banking crisis at all. ${ }^{6}$ If this holds, the exogeneity of the instrument would be violated. Having two instruments for one endogenous regressor allows us to perform an overidentification restriction test to check the exogeneity of the instruments.

The last three columns of Table 3 report the results for the two stage least squares estimator using the exposure to external banking crises and capital flows bonanzas as instruments. ${ }^{7}$ The F-stat related to the first stage estimation is higher than 10, except for the sample that excludes the subset of countries that experienced several banking crises. This suggests that our instruments are in general strong. Concerning the overidentification restriction test, the p-value related to the Sargan test indicates that we cannot reject the hypothesis of instruments' exogeneity. Therefore, exposure to external banking crises and capital flows bonanzas are considered as valid instruments for systemic banking crises.

\footnotetext{
${ }^{6}$ In fact, Mendoza and Terrones (2008) show that though capital flow bonanzas are associated with lending boom, not all lending booms end up as financial crises.

7 We estimate the first-stage regression using the linear probability model using lagged values of both instruments.
} 
Most of all, we again find that the coefficient of the banking crises variable is positive and statistically significant at the five-percent level. Hence the instrumental variables estimations corroborate our baseline results.

Third, we rely on treatment effect models to assess the link between banking crises and democracy. Specifically, the average treatment effects on the treated (ATET) where the treatment is ending a banking crisis and the outcome is the level of democracy can be written as follows:

$$
\beta=E\left(\text { Demo }_{i t}(1)-\text { Demo }_{i t}(0) \mid B C=1, X_{i t}\right)
$$

where Demo(1) denotes the democracy level of a country that experienced a banking crisis, and $\operatorname{Demo}(0)$ denotes the democracy level of the same country if it did not experience a banking crisis. $X$ is a set of covariates.

Treatment effects estimators of $\beta$ rely on the assumption of conditional independence. It stipulates that conditional on the selection of observables in the vector $X$, ending a banking crisis is independent of the level of democracy. Put differently, any other factor that affects the treatment must be independent of the potential levels of democracy and any other factor that affects the potential levels of democracy must be independent of the treatment.

The main difficulty in estimating $\beta$ in the above expression is that we cannot observe $\operatorname{Demo}(0)$ for a country that has been subject to the treatment. The idea of the potential outcomes framework is to build counterfactual level of democracy for countries that received the treatment so as to compare them to their observed democracy level after the treatment. This will produce a consistent estimate of $\beta$ when the conditional independence holds.

Conceptually, since potential outcomes are not observable, the estimation of treatment effects results in a missing data problem. We solve it using different methods, namely regression adjustment (RA), Inverse Probability Weighting (IPW), Doubly-robust (IPWRA), nearest-neighbor matching (NNMatch), and Propensity score matching (PSM) estimators. With these methods, we compute the counterfactual democracy using lagged-values of democracy and time dummies. We use all these five methods and report the results in Table 5.

We start by using the regression adjustment estimator $(R A)$. The idea of this estimator is to construct potential outcomes based on a regression analysis. The goal is to compare the democracy level of a country that experienced a banking crisis to its democracy level if it did not experience the banking crisis. Described by Jordà (2005), this method has been used by Acemoglu et al. (2019) and Lacroix et al. (2017) among others. It proceeds in two steps: first, it fits a regression line of the outcome on a set of covariates. In our case, we construct 
potential democracy levels as a function of lagged-democracy and time dummies for the treated:

$$
\operatorname{Demo}_{i t+s}=\alpha+\sum_{j=1}^{5} \gamma_{j} \text { Demo }_{i t-j}+\lambda_{t}+\beta B C_{i t}+\varepsilon_{i t}
$$

The average treatment effect on the treated is then the average of the difference between observed democracy and predicted democracy over the sample of the treated.

The results corresponding to regression adjustment are displayed in Column (1) of Table 5. They show that the estimated treatment effects banking crisis on democracy is positive and statistically significant at the one-percent level. It equals 0.207 , which means that on average, the level of democracy improves by 0.207 point in the 10 years that follow the occurrence of a banking crisis.

The idea of the inverse probability weighting estimator $(I P W)$ is to construct a treatmenteffects estimator using weighted means with the weights given by the inverse probability of the treatment status. For each observation, we use a logit model to predict the probability of experiencing and ending a banking crisis $\left(P_{i t}\right)$ based on lagged-democracy and time dummies. That is, we estimate the following equation:

$P_{i t}=\rho_{0}+\sum_{j=1}^{5} \rho_{j}$ Demo $_{i t-j}+\lambda_{t}+\varepsilon_{i t}$

For countries who received the treatment, the weight is equal to the reciprocal of the predicted probability of treatment. For subjects who did not receive treatment, the weight is equal to the reciprocal of the predicted probability of not receiving the treatment.

Column (2) of Table 5 reports the estimated treatment effects when we use the inverse probability weighting method. The estimated treatment effect of banking crises on democracy is positive and statistically significant at the five-percent level with a point estimate of 0.201 .

Next, we use the doubly robust estimator (IPWRA): it combines elements of both RA and IPW estimators. We use a linear regression model to predict the level of democracy of each country and a logit model to predict its treatment status. Column (3) of Table 5 reports the results of Doubly Robust estimator. The estimated coefficient of treatment effects is again positive and statistically significant at the five-percent level with a point estimate equal to 0.202 .

Finally, we use the nearest-neighbor matching estimator. It is based on the comparison of the outcomes of subjects that are as similar as possible to the sole exception of their treatment status. In our case, we select a country that experienced a banking crisis and another with similar characteristics but that experienced no banking crisis. The data of each country serve 
as the potential outcome for the other comparable country. We can estimate the treatment effects by comparing the two countries. The last column of Table 5 reports the results of nearest-neighbor matching (NN Match). It shows that the treatment effect on the treated is significantly positive.

Thus, our results with treatment effect models confirm our baseline results that the level of democracy improves in the 10 years that follow the beginning of banking crises.

\section{Extensions}

We have found that the occurrence of a banking crisis contributes to enhance democracy. However we can question whether this impact is the same in all cases. To this end, we extend our baseline results in three directions. First, we check if this impact is influenced by the severity of the banking crisis. Second, we investigate if it is conditional on the country's initial level of democracy. Third, we analyze the timing of the impact to see how it varies over time.

\subsection{Do severe banking crises affect more democracy?}

So far, we have treated all banking crises in the same way. However, banking crises can differ in their severity (Claessens et al., 2012). Yet, the literature on the political economy of reforms stresses that because the reforms may be associated with a reduction in the incumbents' benefits, there could be cases where the incumbent politician opposes the reform agenda (Haggard and Webb, 1993). In line with Andersson (2016), we now test the assumption that severe banking crises are more likely to breakdown the opposition to political reforms.

We therefore check the conditional effect of a banking crisis on democracy, depending on the severity of the crisis. We do so by considering two alternative definitions of the severity of banking crises. According to the first definition, a banking crisis is severe if it lasts more than three years. It is moderate otherwise. According to the second definition, the severity of a banking crisis refers to the peak of non-performing loans during the crisis. In that case, if the share of non-performing loans to the total assets of the banking system exceeds $40 \%$, then the banking crisis is severe. Otherwise it is considered as moderate.

To compare the impact of severe banking crises relative to moderate ones, we consider two sets of dummy variables coding separately severe and moderate crises in the following equation: 


$$
\text { Demo }_{i t}=\alpha_{i}+\mu_{t}+\gamma \text { Demo }_{i t-1}+\beta_{1} B C_{i t}^{\text {Severe }}+\beta_{2} B C_{i t}^{\text {Moderate }}+\sum_{j=1}^{J} \theta_{j} X_{j i t}+\varepsilon_{i t}
$$

$B C_{i t}^{\text {Severe }}$ is a dummy variable that is equal to one in the 10 years that follow the start of a severe banking crisis, and zero otherwise. Likewise, $B C_{i t}^{\text {Moderate }}$ is a dummy variable that is equal to one in the following 10 years of a moderate banking crisis, and zero otherwise.

The reference group in Equation (5) still includes countries that did not experience a systemic banking crisis. We are interested in coefficients $\beta_{1}$ and $\beta_{2}$ : they respectively measure the annual impact of severe and moderate banking crises on the level of democracy.

The first two columns of Table 6 report the results devoted to estimating Equation (5). In the first column, we define severity with respect to the duration; in the second column, we define it according to the peak of non-performing loans.

When using the definition of severity based on the duration of the banking crisis, we observe that the coefficient for severe banking crises is statitistically significant and positive while the coefficient for moderate banking crises is not. This result means that banking crises that last more than three years have a significant effect on democracy while banking crises that last less than three years do not.

When considering the definition of severity related to the peak of non-performing loans, the coefficients of both severe and moderate banking crises are positive and significant. In other words, banking crises characterized by a peak of non-performing loans higher that $40 \%$ have the same impact on democracy as those characterized by a peak of non-performing loans lower than $40 \%$.

Hence, we find limited support for the hypothesis that severe banking crises are more likely to breakdown the opposition to political reforms and thus contribute to greater democratic improvements. It is observed for more severe banking crises in terms of duration but not in terms of the peak of non-performing loans.

\subsection{Does the level of democracy matter?}

Our baseline estimations consider all countries with no distinction regarding the country characteristics. Yet the success of a reform agenda may be conditional several factors including the willingness of the government and its ability to mobilize political support among others. These factors in turn characterize the type of political regimes to some extent. We therefore analyze whether our result is influenced by the level of democracy of the country. 
There are two opposing views on the impact of banking crises on democracy conditional to the level of democracy. On the one hand, there are three arguments supporting the view that this impact would be higher for non-democratic countries. First, non-democratic countries have more room for democratic improvements. Second, pressures for democratic improvements in non-democratic countries are not only internal, but also external, reinforced by international institutions. In line with that, Haggard and Webb (1993) stress that international institutions seek to influence domestic policies through loan conditions in developing countries, most of them being non-democracies. Third, authoritarian regimes can be more successful in initiating reforms than democratic countries thanks to the time horizon of the politicians. Because reforms are usually associated with short term costs and long-term benefits, authoritarian leaders might find it easier to take a longer-term perspective because they face weaker interest-groups and electoral constraints (Haggard and Webb, 1993).

On the other hand, this view is challenged by several arguments according to which democratic countries would be more successful than non-democratic countries in improving democracy after a banking crisis. First, non-democratic countries are characterized by some limitations in freedom to contest the power, which is necessary for triggering democratic reforms (Andersson, 2016). Second, finding the necessary coalition to approve the reform agenda may take time in democratic countries compared to non-democratic countries (Haggard and Webb, 1993).

Thus, the direction of the role played by the initial level of democracy for the impact of banking crises on democracy is theoretically unclear and remains an empirical matter. To investigate that role, we expand Equation (1) to include an interaction between the banking crisis dummy variable and the lagged democracy index. That is, we estimate the following equation:

$\operatorname{Demo}_{i t}=\alpha$ Demo $_{i t-1}+\beta B C_{i t}+\theta B C_{i t} *$ Demo $_{i t-1}+\sum_{j=1}^{J} \theta_{j} X_{j i t}+\delta_{i}+\mu_{t}+\varepsilon_{i t}$

Where $B C_{i t}{ }^{*}$ Demo $_{i t-1}$ denotes the interaction between the banking crises dummy variable and the lagged democracy. In this way, Equation (6) allows the effect of banking crises to depend on democracy via the coefficient $\theta$. The latter represents the incremental effect of banking crises on democracy due to the previous level of democracy.

Column (3) of Table 6 reports the results of the estimation for Equation (6). We still observe that the coefficient of the banking crises dummy is positive and significant. We also 
point out that the coefficient of the interaction between this dummy and lagged democracy is negative and significant. This means that the higher the previous level of democracy, the lower the positive effect of banking crises on democracy. This is illustrated by the fact that the marginal effects are positive and statistically significant at the 5\% level and beyond when they are evaluated at the minimum and at the mean. The highest impact of banking crises on democracy is observed for autocracies. For the highest values of polity2, the marginal effect of banking crises on democracy turns negative, though it is not statistically significant at conventional levels. We consequently find that the impact of banking crises on democracy is conditional on the level of democracy and we support the view that the democratic improvement following a banking crisis is greater for non-democratic countries.

\subsection{The timing of the impact}

We now analyse the timing of the impact of a banking crisis on democracy level to check whether this effect varies over time. In the baseline estimations, we analyse this influence for the ten years following the beginning of a banking crisis. We can investigate the timing of this impact by decomposing the period following the banking crisis.

We do so by estimating Equation (7) below:

Demo $_{i t}=\alpha$ Demo $_{i t-1}+\sum_{j=1}^{5} \beta_{j} * B C_{i t}^{j}+\sum_{k=1}^{K} \theta_{j} X_{k i t}+\delta_{i}+\mu_{t}+\varepsilon_{i t}$

All variables are defined like in Equation (1) except the variables coding the timing of the effect of a financial crisis, $B C_{i t}^{j}(j=1, . ., 5)$. These variables are dummy variables defined as follows: $B C_{i t}^{1}$ takes the value 1 in the three years preceding the beginning of a banking crisis, and 0 elsewhere; $B C_{i t}^{2}$ takes the value 1 in the year in which a banking crisis starts, and in the $1^{\text {st }}$ and $2^{\text {nd }}$ years that follow, and 0 elsewhere; $B C_{i t}^{3}$ takes the value 1 during years 3,4 and 5 that follow the year a banking crisis started, and 0 elsewhere; $B C_{i t}^{4}$ takes the value 1 in the $6^{\text {th }}$, $7^{\text {th }}$, and $8^{\text {th }}$ years that follow the start of a banking crisis, and 0 elsewhere; $B C_{i t}^{5}$ takes the value 1 in the $9^{\text {th }}$, the $10^{\text {th }}$, the $11^{\text {th }}$ and the $12^{\text {th }}$ years following the start of a banking crisis and zero otherwise. Figure (1) below summarizes the specification that looks at the timing in more detail. 
Figure 1: Definition of banking crisis dummies

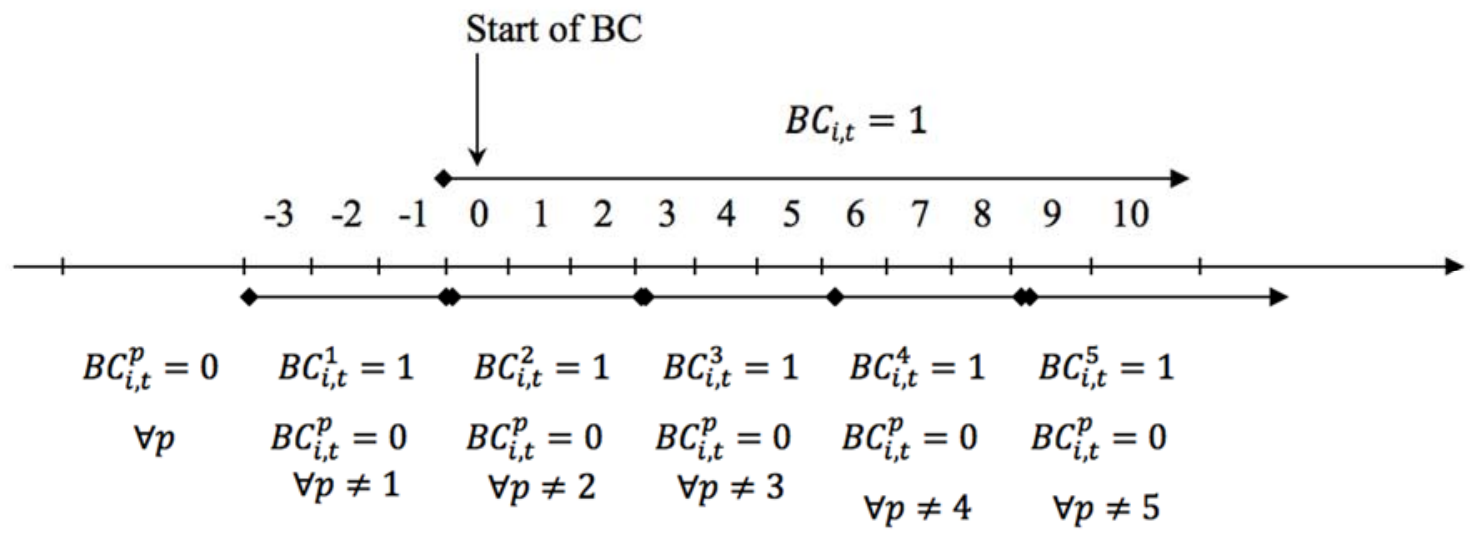

The estimation of equation (7) thus allows the effect of a banking crisis on the level of democracy to vary over time. Moreover, it allows checking the existence of anticipation effects, by looking at coefficient $\beta_{1}$. A significant $\beta_{1}$ would signal that countries that experienced a banking crisis followed a different trajectory before they indeed start it.

Coefficient $\beta_{2}$ measures the impact of banking crises on democracy from the start of a banking crisis to the following two years; $\beta_{3}$ measures the impact of banking crises on democracy from the third to the fifth year that follow the start of banking crises; $\beta_{4}$ measures the impact of banking crises on democracy between the sixth and the eight years that follows the start of banking crises; and $\beta 5$ measures the impact of banking crises on the democracy between the $9^{\text {th }}$ and the $12^{\text {th }}$ year after the banking crisis starts. Altogether, the $\beta_{j}(j=2, \ldots, 5)$ describe the timing of the change in democracy after the crisis started.

Equation (7) therefore allows a finer analysis of the timing of the impact of banking crises on democracy than Equation (1) by differentiating between the time horizons. However, this is done at the cost of imposing more structure on the model.

Table 7 provides the results of estimating Equation (7) for the three specifications of our baseline results: for the whole sample, after excluding a sub-sample of countries that experienced multiple banking crises, and after excluding the Global Financial Crisis.

Several conclusions emerge. First, $\beta_{1}$ is not significant, meaning that there is no anticipation effect. This means that countries covered in our study were on the same trajectory in terms of democracy before the occurrence of a banking crisis. Second, $\beta_{2}$ is not significant, which implies no impact of banking crises on democracy in the two years that follow the start of a banking crisis. Given that the average banking crisis lasts two to three years in our sample, this result means that the democracy index is not affected during the crisis. Third, $\beta_{3}$, 
$\beta_{4}$, and $\beta_{5}$ are all positive and statistically significant. This result implies that democracy improves from the $3^{\text {rd }}$ to the $12^{\text {th }}$ years that follow the beginning of a banking crisis.

Overall the results show that on average the bulk of the improvement in democracy that we observe in our baseline results materializes from the third year after the beginning of a banking crisis while there is no effect in the first two years. This conclusion can come from the fact that governments and policymakers are more concerned about resolving the crisis in the two years following its start. But once the crisis is resolved, reforms are proposed for sound political institutions. The implementation of the reform agenda may take some time, at least three years.

\section{Conclusion}

This paper examines the impact of banking crises on the level of democracy. We find that banking crises tend to be followed by an improvement in democracy. We interpret this result by the fact that banking crises are major negative shocks to the economy which serve as a triggering event to contest power in autocracies. This result is robust to a battery of robustness checks including changing the definition of democracy, controlling for other income shocks, and using instrumental variables, treatment effect models, and dynamic panel data estimators. We observe that the impact of a banking crisis on democratic change is greater in non-democratic countries and when the banking crisis is severe in the sense that it lasts more than three years. Finally, we find that the bulk of the improvement in democracy that we observe in our baseline results materializes from the third year after the start of a banking crisis while there is no effect in the first two years.

Our paper contributes to a better understanding of the aftermath of banking crises. Next to their detrimental economic consequences, these events can favor democratization in line with Peter Bernholz's $(1995,2000)$ presumption that they can open a window of opportunity for reform. This conclusion does not mean that a banking crisis is required for democratic improvement but suggests that autocrats fearing political changes have an incentive to avoid them. 


\section{References}

Acemoglu, D., Johnson, S., Robinson, J. and Thaicharoen, Y., 2003. Institutional causes, macroeconomic symptoms: volatility, crises and growth. Journal of Monetary Economics, 50(1), 49-123.

Acemoglu, D., Naidu, S., Restrepo, P., \& Robinson, J. A. (2019). Democracy does cause growth, Journal of Political Economy, 127(1), 47-100.

Acemoglu, D., and Robinson, J., 2001. A theory of political transitions. American Economic Review, 91(4), 938-963.

Andersson, F.N., 2016. A blessing in disguise? Banking crises and institutional change. World Development 83, 135-147.

Bernholz, P., 1979. Freedom and constitutional economic order. Journal of Institutional and Theoretical Economics, 135, 510-532.

Bernholz, P.,1991. The constitution of totalitarianism. Journal of Institutional and Theoretical Economics, 147, 425-440.

Bernholz P., 1995. Causes of changes in political-economic regimes. In: Gerken L. (ed) Competition among Institutions. Palgrave Macmillan, London.

Bernholz, P., 2000. Democracy and capitalism: Are they compatible in the long-run? Journal of Evolutionary Economics, 10: 3-16.

Bernholz, P., 2010. Politics, financial crisis, central bank constitution and monetary policy (Freiburger Diskussionspapiere zur Ordnungsökonomik, 10/5). Freiburg: Walter Eucken Institut.

Bluhm, R., Crombrugghe, D.D. and Szirmai, A., 2019. Do weak institutions prolong crises? On the identification, characteristics, and duration of declines during economic slumps. World Bank Economic Review (forthcoming).

Brückner, M. and Ciccone, A., 2011. Rain and the democratic window of opportunity. Econometrica, 79(3), 923-947.

Burke, P.J. and Leigh, A., 2010. Do output contractions trigger democratic change?. American Economic Journal: Macroeconomics, 2(4), 124-157.

Caballero, J.A., 2014. Do surges in international capital inflows influence the likelihood of banking crises? The Economic Journal, 126(591), 281-316.

Carvalho, D., 2014. The real effects of government-owned banks: evidence from an emerging market. Journal of Finance 69 (2), 577-609. 
Chodorow-Reich, G., 2014. The employment effects of credit market disruptions: firm-level evidence from the 2008-9 financial crisis. Quarterly Journal of Economics, 129 (1), 1659.

Claessens, S., Klingebiel, D. and Laeven, L., 2002. Financial restructuring in banking and corporate sector crises: Which policies to pursue? in D. Klingebiel et L. Laeven (eds.) Managing the real and fiscal effects of banking crises, 428, World Bank, 1-13.

Coppedge, M., Lindberg, S., Skaaning, S.E. and Teorell, J., 2016. Measuring high level democratic principles using the V-Dem data. International Political Science Review, $37(5), 580-593$.

Demirgüç-Kunt, A. and Detragiache, E., 1998. The determinants of banking crises in developing and developed countries. IMF Staff Papers, 45(1), pp.81-109.

Dinc, S., 2005. Politicians and banks: political influences on government-owned banks in emerging countries. Journal of Financial Economics 77, 453-479.

Englmaier, F., Stowasser, T., 2017. Electoral cycles in savings bank lending. Journal of the European Economic Association 15 (2), 296-354.

Funke, M., Schularick, M., Trebesch, C. 2016. Going to extremes: politics after financial crises, 1870-2014. European Economic Review 88, 227-260.

Gries, T. and Meierrieks, D., 2013. Do banking crises cause terrorism?. Economics Letters, 119(3), 321-324.

Gutmann, J., Pfaff, K. and Voigt, S., 2017. Banking crises and human rights. Applied Economics Letters, 1-4.

Haggard, S. and Webb, S.B., 1993. What do we know about the political economy of economic policy reform? The World Bank Research Observer, 8(2), 143-168.

Hoggarth, G., Reis, R., Saporta, V., 2002. Costs of banking system instability: some empirical evidence. Journal of Banking and Finance 26, 825-855.

Jordà, Ò., 2005. Estimation and inference of impulse responses by local projections. American Economic Review, 95(1), pp.161-182.

Kaminsky, G., Reinhart, C. 1999. The twin crises: the causes of banking and balance-ofpayments problems. American Economic Review 89, 473-500.

Ivashina, V., Scharstein, D., 2010. Bank lending during the financial Crisis of 2008. Journal of Financial Economics 97 (1), 319-338.

Kuran, T., 1989. Sparks and prairie fires: a theory of unanticipated political revolution. Public Choice 61 (1), 41-74. 
Kuran, T., 1991. Now out of never: The element of surprise in the East European revolution of 1989. World Politics 44 (1), 7-48.

Lacroix, J., Méon, P.G. and Sekkat, K., 2017. Do democratic transitions attract foreign investors and how fast? (No. 17-006). ULB-Universite Libre de Bruxelles.

Laeven, L. and Valencia, F., 2008. Systemic banking crises: a new database, International Monetary Fund, Working Paper No. 08/224

Laeven, L. and Valencia, F., 2012. Systemic banking crises database: An update, International Monetary Fund, Working Paper No. 12/163.

Lipset, S.M., 1959. Some social requisites of democracy: Economic development and political legitimacy. American Political Science Review, 53 (1), 69-105.

Marshall, M.G., Gurr, T.R. and Jaggers, K., 2017. Polity IV project: Political regime characteristics and transitions, 1800-2016. Center for Systemic Peace.

Mendoza, E.G. and Terrones, M.E., 2008. An anatomy of credit booms: evidence from macro aggregates and micro data (No. w14049). National Bureau of Economic Research.

Reinhart, C.M. and Reinhart, V.R., 2008. Capital flow bonanzas: an encompassing view of the past and present (No. w14321). National Bureau of Economic Research.

Reinhart, C.M. and Rogoff, K.S., 2009. This time is different: Eight centuries of financial folly. Princeton University Press

Reinhart, C.M. and Rogoff, K.S., 2013. Banking crises: an equal opportunity menace. Journal of Banking \& Finance, 37(11), 4557-4573.

Roodman, D., 2009. How to do xtabond2: An introduction to difference and system GMM in Stata. The Stata Journal, 9(1), pp.86-136.

Schularick, M., Taylor, A., 2012. Credit booms gone bust: monetary policy, leverage cycles, and financial crises. American Economic Review 102, 1029-1061. 
Table 1: Baseline Results

\begin{tabular}{|lccc|}
\hline Dependent Variable: Democracy & \multicolumn{3}{c|}{ Before/After } \\
\cline { 2 - 4 } & Whole Sample & $\begin{array}{c}\text { Multiple crises } \\
\text { countries } \\
\text { excluded }\end{array}$ & $\begin{array}{c}\text { Subprime crisis } \\
\text { period excluded }\end{array}$ \\
\hline Demo (t-1) & 0.874 & 0.871 & 0.873 \\
BC 10 years after the start & $(74.69)^{* * *}$ & $(66.75)^{* * *}$ & $(73.21)^{* * *}$ \\
Constant & 0.196 & 0.209 & 0.219 \\
& $(2.130)^{* *}$ & $(2.083)^{* *}$ & $(2.223)^{* *}$ \\
Observations & -0.431 & -0.311 & -0.424 \\
Number of countries & $(-2.234)^{* *}$ & $(-1.900)^{*}$ & $(-2.208)^{* *}$ \\
Adjusted R-squared & & & \\
Country FE & 4,132 & 3,618 & 3,800 \\
Year FE & 129 & 114 & 128 \\
Tab & 0.845 & 0.837 & 0.835 \\
& YES & YES & YES \\
\hline
\end{tabular}

Table 1 reports the results for estimating Equation (1) using OLS. Column (1) focuses on the whole sample; Column (2) excludes the subsample of countries that experienced several banking crises over the period of study. Column (3) excludes the 2008 Subprime crisis. In All columns, we control for both country and year fixed effects. Standard errors are clustered at country level. The corresponding t-statistics are in parentheses. $* * *$ $\mathrm{p}<0.01$ indicates statistical significance at $1 \% ; * * \mathrm{p}<0.05$ indicates statistical significance at $5 \%$; $\mathrm{p}<0.1$ indicates statistical significance at $10 \%$. 
Table 2: Robustness Checks

\begin{tabular}{|l|cc|c|}
\hline \multirow{4}{*}{ Dependent variable : Democracy } & $\begin{array}{c}\text { BC : from Laeven and Valencia } \\
(2008 \text { and 2012) }\end{array}$ & \multirow{2}{*}{$\begin{array}{c}\text { BC: Reinhart } \\
\text { and Rogoff } \\
\text { database }\end{array}$} \\
\cline { 2 - 3 } & $\begin{array}{c}\text { Former } \\
\text { Socialist } \\
\text { countries } \\
\text { excluded }\end{array}$ & $\begin{array}{c}\text { Controlling for } \\
\text { Regional } \\
\text { Waves of } \\
\text { Democracy }\end{array}$ & \\
\cline { 1 - 2 } Demo (t-1) & 0.876 & 0.866 & 0.875 \\
BC 10 years after the start & $(73.45)^{* * *}$ & $(66.27)^{* * *}$ & $(75.90)^{* * *}$ \\
Regional Demo & 0.224 & 0.208 & 0.158 \\
Constant & $(2.390)^{* *}$ & $(2.238)^{* *}$ & $(2.150)^{* *}$ \\
& \multicolumn{3}{|c}{} \\
Observations & -0.415 & $(3.044)^{* * *}$ & \\
Number of countries & -0.276 & -0.418 \\
Adjusted R-squared & $(-2.153)^{* *}$ & $(-1.440)$ & $(-2.166)^{* *}$ \\
Country FE & 4,037 & 4,097 & 4,176 \\
Year FE & 124 & 128 & 129 \\
\hline
\end{tabular}

Table 2 is dedicated to robustness checks. In Column (1), we exclude the sub-sample of former socialist countries, Column (2) controls for regional waves of democracy and Column (3) uses the Reinhart and Rogoff (2009) dataset to identify banking crises. In all columns, we control for country and year fixed effects. Standard errors are clustered at country level. The corresponding t-statistics are in parentheses. ${ }^{* * *} \mathrm{p}<0.01$ indicates statistical significance at $1 \% ;{ }^{* *} \mathrm{p}<0.05$ indicates statistical significance at $5 \% ;{ }^{*} \mathrm{p}<0.1$ indicates statistical significance at $10 \%$. 
Table 3: Controlling for Other Income Shocks

\begin{tabular}{|lccc|}
\hline Dependent Variable : Democracy & $\begin{array}{c}\text { Before/After } \\
\text { Large Income } \\
\text { Shocks }\end{array}$ & $\begin{array}{c}\text { Sovereign Debt } \\
\text { Crises }\end{array}$ & $\begin{array}{c}\text { Currency } \\
\text { Crises }\end{array}$ \\
\hline Demo (t-1) & 0.874 & 0.874 & 0.873 \\
BC 10 years after the start & $(74.71)^{* * *}$ & $(73.89)^{* * *}$ & $(74.45)^{* * *}$ \\
& 0.189 & 0.169 & 0.193 \\
10 years after Large Income Shocks & $(2.051)^{* *}$ & $(1.893)^{*}$ & $(2.046)^{* *}$ \\
& 0.178 & & \\
Sovereign Debt crisis 10 years after & $(1.210)$ & & \\
& & 0.298 & \\
Currency crisis 10 years after & & $(1.884)^{*}$ & 0.0331 \\
& & & $(0.416)$ \\
Constant & -0.433 & -0.428 & -0.433 \\
& $(-2.246)^{* *}$ & $(-2.236)^{* *}$ & $(-2.251)^{* *}$ \\
Observations & & & \\
Number of countries & 4,132 & 4,132 & 4,126 \\
Adjusted R-squared & 129 & 129 & 129 \\
Country FE & 0.845 & 0.845 & 0.844 \\
Year FE & YES & YES & YES \\
\hline
\end{tabular}

Table 3 controls for other income shock focusing respectively on large income shocks (Column (1)), sovereign debt crises (Column (2)) and currency crises (Column (3)). In all columns, we control for country and year fixed effects. Standard errors are clustered at country level. The corresponding t-statistics are in parentheses. *** $\mathrm{p}<0.01$ indicates statistical significance at $1 \% ;{ }^{* *} \mathrm{p}<0.05$ indicates statistical significance at $5 \% ; * \mathrm{p}<0.1$ indicates statistical significance at $10 \%$. 
Table 4: Other Estimation Techniques

\begin{tabular}{|c|c|c|c|c|c|c|}
\hline \multirow[b]{2}{*}{ Dependent variable: Democracy } & \multicolumn{3}{|c|}{ Dynamic Panel Data } & \multicolumn{3}{|c|}{ IV estimation } \\
\hline & $\begin{array}{l}\text { Whole } \\
\text { Sample }\end{array}$ & $\begin{array}{l}\text { Multiple } \\
\text { crises } \\
\text { countries } \\
\text { excluded }\end{array}$ & $\begin{array}{l}\text { Subprime } \\
\text { crisis } \\
\text { excluded }\end{array}$ & $\begin{array}{l}\text { Whole } \\
\text { Sample }\end{array}$ & $\begin{array}{l}\text { Multiple } \\
\text { crises } \\
\text { countries } \\
\text { excluded }\end{array}$ & $\begin{array}{l}\text { Subprime } \\
\text { crisis } \\
\text { excluded }\end{array}$ \\
\hline Demo $(t-1)$ & $\begin{array}{c}0.928 \\
(122.7)^{* * *}\end{array}$ & $\begin{array}{c}0.905 \\
(119.0)^{* * *}\end{array}$ & $\begin{array}{c}0.946 \\
(124.3)^{* * *}\end{array}$ & $\begin{array}{c}0.867 \\
(68.35)^{* * *}\end{array}$ & $\begin{array}{c}0.864 \\
(61.38)^{* * *}\end{array}$ & $\begin{array}{c}0.867 \\
(65.32)^{* * *}\end{array}$ \\
\hline BC 10 years after the start & $\begin{array}{c}0.161 \\
(5.462)^{* * *}\end{array}$ & $\begin{array}{c}0.141 \\
(4.713)^{* * *}\end{array}$ & $\begin{array}{c}0.220 \\
(7.421)^{* * *}\end{array}$ & $\begin{array}{c}0.818 \\
(2.036)^{* *}\end{array}$ & $\begin{array}{c}0.865 \\
(2.124)^{* *}\end{array}$ & $\begin{array}{c}0.880 \\
(2.007)^{* *}\end{array}$ \\
\hline Constant & $\begin{array}{c}0.716 \\
(7.816)^{* * *}\end{array}$ & $\begin{array}{c}-0.369 \\
(-4.589)^{* * *}\end{array}$ & $\begin{array}{c}-0.291 \\
(-2.913) * * *\end{array}$ & $\begin{array}{c}-0.355 \\
(-2.337)^{* *}\end{array}$ & $\begin{array}{c}-0.399 \\
(-2.653)^{* * *}\end{array}$ & $\begin{array}{c}-0.590 \\
(-3.382)^{* * *}\end{array}$ \\
\hline P-value of: & & & & & & \\
\hline Arellano and Bond AR(1) & 0.000 & 0.000 & 0.000 & & & \\
\hline Arellano and Bond AR(2) & 0.586 & 0.727 & 0.998 & & & \\
\hline Sargan test of Overidentification & 0.374 & 0.237 & 0.049 & 0.638 & 0.947 & 0.612 \\
\hline Hansen test of Overidentification & 0.122 & 0.319 & 0.301 & & & \\
\hline F-stat First Stage & & & & 11.645 & 9.226 & 10.251 \\
\hline P-value & & & & 0.000 & $(0.000)$ & $(0.000)$ \\
\hline Observations & 4,132 & 3,618 & 3,800 & 4,059 & 3,549 & 3,754 \\
\hline R-squared & & & & 0.953 & 0.954 & 0.953 \\
\hline Number of countries & 129 & 114 & 128 & 128 & 113 & 127 \\
\hline Country FE & YES & YES & YES & YES & YES & YES \\
\hline Year FE & YES & YES & YES & YES & YES & YES \\
\hline
\end{tabular}

Table 4 provides robustness checks regarding the estimation techniques. In the first three columns using the Blundell and Bond estimator. The last three columns estimate our baseline results using both the exposure to banking crises and surges in capital flow bonanzas as instruments for banking crises. In all columns, we control for both country and year fixed effects. The standard errors are clustered at the country level. The corresponding $\mathrm{t}$-statistics are in parentheses. $* * * \mathrm{p}<0.01$ indicates statistical significance at $1 \% ; * * \mathrm{p}<0.05$ indicates statistical significance at $5 \% ; * \mathrm{p}<0.1$ indicates statistical significance at $10 \%$.

To report the Sargan test of overidentification, we relax the assumption of clustered standard errors. 
Table 5: Average Treatment Effects on the Treated

\begin{tabular}{|lcccc|}
\hline $\begin{array}{l}\text { Dependent Variable : } \\
\text { Democracy }\end{array}$ & $(1)$ & $(2)$ & $(3)$ & $(4)$ \\
& RA & IPW & IPWRA & NN Match \\
BC 10 years after the start & 0.202 & 0.201 & 0.202 & 0.327 \\
& $(2.634)^{* * *}$ & $(2.141)^{* *}$ & $(2.543)^{* *}$ & $(2.329)^{* *}$ \\
Observations & 3,563 & 3,563 & 3,563 & 3,563 \\
Country FE & YES & YES & YES & YES \\
Year FE & YES & YES & YES & YES \\
\hline
\end{tabular}

Table 5 estimates the impact of banking crises using treatment effects models. We use successively the RA estimator (Column (1)), the IPW estimator (Column (2)), the IPWRA estimator (Column (3)), and the NN Match estimator (Column (4)). The standard errors are clustered at the country level. The corresponding t-statistics are in parentheses. ${ }^{* * *} \mathrm{p}<0.01$ indicates statistical significance at $1 \%$; $* * \mathrm{p}<0.05$ indicates statistical significance at $5 \% ; * \mathrm{p}<0.1$ indicates statistical significance at $10 \%$. 
Table 6: Conditional Effects of Banking Crises and Democracy

\begin{tabular}{|c|c|c|c|}
\hline \multirow[b]{2}{*}{$\begin{array}{l}\text { Dependent Variable : } \\
\text { Democracy }\end{array}$} & \multicolumn{2}{|c|}{ Severity } & \multirow[t]{2}{*}{ By degree of democracy } \\
\hline & Duration & NPL & \\
\hline Demo (t-1) & $\begin{array}{c}0.875 \\
(75.58)^{* * *}\end{array}$ & $\begin{array}{c}0.880 \\
(78.52)^{* * *}\end{array}$ & $\begin{array}{c}0.883 \\
(71.91)^{* * *}\end{array}$ \\
\hline Severe BC & $\begin{array}{c}0.247 \\
(2.076)^{* *}\end{array}$ & & \\
\hline Moderate BC & $\begin{array}{l}0.0756 \\
(0.599)\end{array}$ & & \\
\hline Severe BC & & $\begin{array}{c}0.433 \\
(2.213)^{* *}\end{array}$ & \\
\hline Moderate BC & & $\begin{array}{c}0.337 \\
(2.497)^{* *}\end{array}$ & \\
\hline BC 10 years after the start & & & $\begin{array}{c}0.246 \\
(2.352)^{* *}\end{array}$ \\
\hline $\operatorname{Demo}(\mathrm{t}-1) \times \mathrm{BC}$ & & & $\begin{array}{c}-0.0343 \\
(-2.925)^{* * *}\end{array}$ \\
\hline Constant & $\begin{array}{c}-0.416 \\
(-2.160)^{* *}\end{array}$ & $\begin{array}{c}-0.392 \\
(-2.009)^{* *}\end{array}$ & $\begin{array}{c}-0.423 \\
(-2.195)^{* *}\end{array}$ \\
\hline \multicolumn{4}{|l|}{ Marginal effects at the : } \\
\hline - $\quad$ Minimum & & & $\begin{array}{c}0.590 \\
(2.98)^{* * *}\end{array}$ \\
\hline Mean & & & $\begin{array}{c}0.192 \\
(1.97)^{* *}\end{array}$ \\
\hline Maximum & & & $\begin{array}{l}-0.097 \\
(-0.89)\end{array}$ \\
\hline Observations & 4,176 & 3,777 & 4,132 \\
\hline Number of countries & 129 & 129 & 129 \\
\hline Adjusted R-squared & 0.845 & 0.852 & 0.845 \\
\hline Country FE & YES & YES & YES \\
\hline Year FE & YES & YES & YES \\
\hline $\begin{array}{l}\text { Table } 6 \text { reports the results of bar } \\
\text { democracy (Column (3)). For th } \\
\text { minimum, at the mean, and at the } \\
\text { to the duration of the crisis while } \\
\text { columns, we control for both co } \\
\text { level. The corresponding t-statist } \\
\text { p }<0.05 \text { indicates statistical signifi }\end{array}$ & $\begin{array}{l}\text { ses depending o } \\
\text { we also report t } \\
\text { m. In Column ( } \\
\text { nn (2) it is defin } \\
\text { d year fixed eff } \\
\text { n parentheses. * } \\
5 \% ; * \text { p }<0.1 \text { ind }\end{array}$ & $\begin{array}{l}\text { ir severity (cc } \\
\text { harginal effect } \\
\text { he severity of } \\
\text { iccording the } \mathrm{s} \\
\text { The standard } \\
\text { o }<0.01 \text { indicat } \\
\text { es statistical sis }\end{array}$ & $\begin{array}{l}\text { Imns (1) and (2)) and the level } \\
\text { of banking crises evaluated at t } \\
\text { anking crisis is defined accordir } \\
\text { re of non-performing loans. In } \\
\text { rrors are clustered at the count } \\
\text { statistical significance at } 1 \% \text {; } \\
\text { ificance at } 10 \% \text {. }\end{array}$ \\
\hline
\end{tabular}


Table 7: Timing of the Impact

\begin{tabular}{|lccc|}
\hline & \multicolumn{3}{c|}{ Periods around the start of a banking crisis } \\
\cline { 2 - 4 } Dependent Variable : Democracy & Whole Sample & $\begin{array}{c}\text { Multiple crises } \\
\text { countries } \\
\text { excluded }\end{array}$ & $\begin{array}{c}\text { Global } \\
\text { Financial Crisis } \\
\text { excluded }\end{array}$ \\
\hline Demo (t-1) & 0.873 & 0.869 & 0.872 \\
BC 3 years before the start & $(72.71)^{* * *}$ & $(65.15)^{* * *}$ & $(70.80)^{* * *}$ \\
& 0.0331 & -0.0235 & 0.0430 \\
BC 0 to 2 years after the start & $(0.214)$ & $(-0.127)$ & $(0.274)$ \\
& 0.0522 & 0.0831 & 0.0716 \\
BC 3 to 5 years after the start & $(0.332)$ & $(0.405)$ & $(0.439)$ \\
& 0.355 & 0.341 & 0.380 \\
BC 6 to 8 years after the start & $(2.224)^{* *}$ & $(2.021)^{* *}$ & $(2.278)^{* *}$ \\
& 0.265 & 0.303 & 0.295 \\
BC 9 to 12 years after the start & $(2.374)^{* *}$ & $(2.481)^{* *}$ & $(2.475)^{* *}$ \\
& 0.197 & 0.231 & 0.222 \\
Constant & $(2.220)^{* *}$ & $(2.113)^{* *}$ & $(2.203)^{* *}$ \\
& -0.431 & -0.311 & -0.423 \\
Observations & $(-2.240)^{* *}$ & $(-1.904)^{*}$ & $(-2.218)^{* *}$ \\
Number of countries & & & \\
Adjusted R-squared & 4,132 & 3,618 & 3,800 \\
Country FE & 129 & 114 & 128 \\
Year FE & 0.845 & 0.837 & 0.836 \\
Yeas & YES & YES & YES \\
Y & & YES \\
\hline
\end{tabular}

Table 7 estimates Specification (2) which looks at the sub-periods around the occurrence of banking crises. Column (1) focuses on the whole sample; Column (2) excludes the subsample of countries that experienced several banking crises over the period of study. Column (3) excludes the 2008 Subprime crisis. In All columns, we control for both country and year fixed effects. Standard errors are clustered at country level. The corresponding t-statistics are in parentheses. ${ }^{* * *} \mathrm{p}<0.01$ indicates statistical significance at $1 \% ; * * \mathrm{p}<0.05$ indicates statistical significance at $5 \% ;{ }^{*} \mathrm{p}<0.1$ indicates statistical significance at $10 \%$. 
Appendix A:

Table A1: List of countries and banking crises

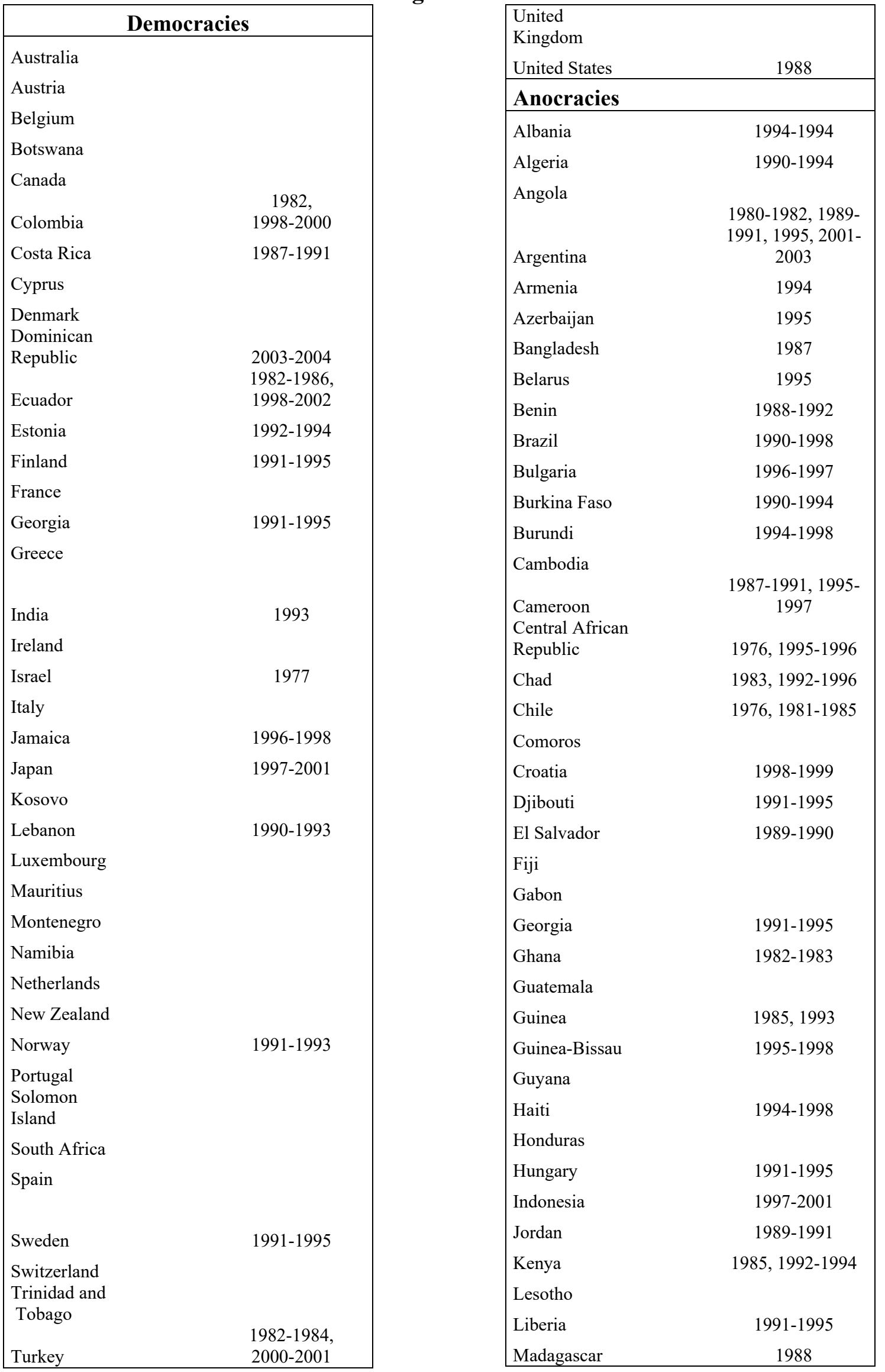




\begin{tabular}{|c|c|}
\hline \multicolumn{2}{|l|}{ Malawi } \\
\hline Malaysia & 1997-1999 \\
\hline Mali & 1987-1991 \\
\hline Mauritania & $\begin{array}{c}1984 \\
1981-1985,1994-\end{array}$ \\
\hline Mexico & 1996 \\
\hline Mozambique & $1987-1991$ \\
\hline Nepal & 1988 \\
\hline Nicaragua & 1990 \\
\hline Niger & $1983-1985$ \\
\hline Nigeria & 1991-1995 \\
\hline \multicolumn{2}{|l|}{ Pakistan } \\
\hline \multicolumn{2}{|l|}{$\begin{array}{l}\text { Papua New } \\
\text { Guinea }\end{array}$} \\
\hline Paraguay & 1995 \\
\hline Philippines & $\begin{array}{c}1983 \\
1983-1986,1997- \\
2001\end{array}$ \\
\hline Poland & 1992 \\
\hline Romania & 1990-1992 \\
\hline \multicolumn{2}{|l|}{ Rwanda } \\
\hline Senegal & $1988-1991$ \\
\hline Sierra Leone & 1990-1994 \\
\hline \multicolumn{2}{|l|}{ Singapore } \\
\hline Sri Lanka & 1989-1991 \\
\hline \multicolumn{2}{|l|}{ Suriname } \\
\hline Tanzania & $1987-1988$ \\
\hline Thailand & $1983,1997-2000$ \\
\hline Togo & 1993-1994 \\
\hline Tunisia & 1991 \\
\hline Uganda & $\begin{array}{c}1994 \\
1981-1985,2002- \\
2005\end{array}$ \\
\hline Zambia & 1995-1998 \\
\hline Zimbabwe & 1995-1999 \\
\hline \multicolumn{2}{|c|}{ Autocracies } \\
\hline \multicolumn{2}{|l|}{ Afghanistan } \\
\hline \multicolumn{2}{|l|}{ Bahrain } \\
\hline \multicolumn{2}{|l|}{ Bhutan } \\
\hline China & 1998 \\
\hline $\begin{array}{l}\text { Cuba } \\
\text { Equatorial } \\
\text { Guinea }\end{array}$ & 1983 \\
\hline Eritrea & 1993 \\
\hline \multicolumn{2}{|l|}{ Iraq } \\
\hline Kuwait & $1982-1985$ \\
\hline \multicolumn{2}{|l|}{ Lao PDR } \\
\hline Libya & \\
\hline
\end{tabular}

\begin{tabular}{|lc|}
\hline Morocco & $1980-1984$ \\
Myanmar & \\
Oman & \\
Qatar & \\
Saudi Arabia & \\
Somalia & \\
Swaziland & $1995-1999$ \\
\hline
\end{tabular}

The countries are classified according to their average polity2 score over the period 1975-2010 based on criteria in the Polity IV dataset. For instance, when the average democracies have a score between 6 and 10; anocracies have a score between -6 and 6 ; autocracies have a score between -10 and -6 . 
Table A2: Variables' description and sources

\begin{tabular}{|c|c|c|}
\hline Variables & Description & Sources \\
\hline Polity2 & Variable coding political regimes. & $\begin{array}{l}\text { Marshall, Gurr and } \\
\text { Jaggers (2016) }\end{array}$ \\
\hline $\mathrm{BC}$ & A dummy variable indicating banking crises & $\begin{array}{l}\text { Laeven and Valencia (2008, } \\
\text { 2012) }\end{array}$ \\
\hline $\mathrm{BC}^{1}$ & $\begin{array}{l}\text { Dummy variable that takes value } 1 \text { in the } 3 \text { years } \\
\text { that precedes the occurrence of a banking crisis }\end{array}$ & $\begin{array}{l}\text { Authors' coding based on Laeven } \\
\text { and Valencia }(2008,2012)\end{array}$ \\
\hline $\mathrm{BC}^{2}$ & $\begin{array}{l}\text { Dummy variable that takes value } 1 \text { in the year of } \\
\text { the occurrence of a banking crisis and in the } \\
\text { following } 2 \text { years }\end{array}$ & $\begin{array}{l}\text { Authors' coding based on Laeven } \\
\text { and Valencia }(2008,2012)\end{array}$ \\
\hline $\mathrm{BC}^{3}$ & $\begin{array}{l}\text { Dummy variable that takes value } 1 \text { from the } 3^{\text {rd }} \text { to } \\
\text { the } 5^{\text {th }} \text { years that follow the occurrence of a banking } \\
\text { crisis }\end{array}$ & $\begin{array}{l}\text { Authors' coding based on Laeven } \\
\text { and Valencia }(2008,2012)\end{array}$ \\
\hline $\mathrm{BC}^{4}$ & $\begin{array}{l}\text { Dummy variable that takes value } 1 \text { from the } 6^{\text {th }} \text { to } \\
\text { the } 8^{\text {th }} \text { years that follow the occurrence of a banking } \\
\text { crisis }\end{array}$ & $\begin{array}{l}\text { Authors' coding based on Laeven } \\
\text { and Valencia }(2008,2012)\end{array}$ \\
\hline $\mathrm{BC}^{5}$ & $\begin{array}{l}\text { Dummy variable that takes value } 1 \text { from the } 9^{\text {th }} \text { to } \\
\text { the } 10^{\text {th }} \text { years that follow the occurrence of a } \\
\text { banking crisis }\end{array}$ & $\begin{array}{l}\text { Authors' coding based on Laeven } \\
\text { and Valencia }(2008,2012)\end{array}$ \\
\hline Severe BC & $\begin{array}{l}\text { A banking crisis that last more than } 3 \text { years or a } \\
\text { banking crisis characterized by a share of } \\
\text { nonperforming loans higher than } 40 \%\end{array}$ & $\begin{array}{l}\text { Authors' coding based on Laeven } \\
\text { and Valencia }(2008,2012)\end{array}$ \\
\hline \begin{tabular}{|l|} 
Moderate \\
BC \\
\end{tabular} & A banking crisis that is not severe. & $\begin{array}{l}\text { Authors' coding based on Laeven } \\
\text { and Valencia }(2008,2012)\end{array}$ \\
\hline $\begin{array}{l}\text { Regional } \\
\text { Demo }\end{array}$ & Index of regional democracy & $\begin{array}{l}\text { Authors calculation based on the } \\
\text { Polity IV dataset }\end{array}$ \\
\hline $\begin{array}{l}\text { Large } \\
\text { income } \\
\text { shocks } \\
\end{array}$ & $\begin{array}{l}\text { Dummy variables identifying dates of large income } \\
\text { shocks }\end{array}$ & Bluhm et al. (2019) \\
\hline \begin{tabular}{|l|} 
Sovereign \\
debt crises
\end{tabular} & $\begin{array}{l}\text { Dummy variables identifying dates of sovereign } \\
\text { debt crises }\end{array}$ & $\begin{array}{l}\text { Laeven and Valencia (2008, } \\
\text { 2012) }\end{array}$ \\
\hline $\begin{array}{l}\text { Currency } \\
\text { crises }\end{array}$ & $\begin{array}{l}\text { Dummy variables identifying dates of currency } \\
\text { crises }\end{array}$ & $\begin{array}{l}\text { Laeven and Valencia (2008, } \\
\text { 2012) }\end{array}$ \\
\hline $\begin{array}{l}\text { Exposure to } \\
\text { external } \\
\text { banking } \\
\text { crises }\end{array}$ & $\begin{array}{l}\text { An instrumental variable capturing a country's } \\
\text { exposure to external banking crises }\end{array}$ & $\begin{array}{l}\text { Authors calculation based on the } \\
\text { Polity IV dataset }\end{array}$ \\
\hline $\begin{array}{l}\text { Capital flow } \\
\text { bonanzas }\end{array}$ & $\begin{array}{l}\text { Dummy variable indicating surges in capital } \\
\text { inflows. }\end{array}$ & Reinhart and Rogoff (2008) \\
\hline
\end{tabular}

